\title{
PENGGUNAAN LEARNING MANAGEMENT SYSTEM (LMS) DI PERGURUAN TINGGI: STUDI KASUS DI UNIVERSITAS PENDIDIKAN INDONESIA
}

\author{
Munir \\ (Universitas Pendidikan Indonesia, munir@upi.edu, HP: 08157021112)
}

\begin{abstract}
Factors Affecting the Use of the Learning Management System in Universities (A Case Study in Indonesia University of Education). The purpose of this paper is to find out factors that affect the usage of the Learning Management System (LMS) in in Indonesia University of Education. Indonesia University of Education has been built LMS to support learning processes. The focus is on factors affecting the use of LMS in supporting effective and efficient learning processes. In this research the writer used Technology Acceptance Model (TAM) to find out those factors. The data were collected using the survey technique and were analyzed by means of the multivariate statistic method. The result of this research concluded that the factors of Perceived Usefulness (PU), Perceived Ease of Use (PEOU), Intention to Use (ITU), Actual Usage Behavior (AUB) significantly affected the effective and efficient use of LMS in supporting learning processes.
\end{abstract}

Keywords: Learning Management System (LMS), Technology Acceptance Model (TAM), Information and Communication technology (ICT).

\section{PENDAHULUAN}

Kemajuan teknologi informasi dan komunikasi (TIK) dalam bidang pendidikan membuka cakrawala baru bagi pembukaan kesempatan (akses) dan peningkatan mutu pendidikan di semua jenjang,jalur, dan jenis pendidikan. Pendidikan dengan memanfaatkan sistem pembelajaran secara tatap muka tetap merupakan model utama pendidikan, tetapi model pembelajaran on-line sudahlamajugaberkembang, terutama untuk pendidikan bagi orang dewasa dan mandiri, mahasiswa dipandang memiliki kedewasaan dan kemandirian dalam proses pembelajaran sehingga akan mampu melaksanakan pembelajaran online.
Pembelajaran online yangdimaksudkan adalah berbasis pada TIK dengan menggunakan internet sebagai media utama.Tatap muka dilakukan hanya beberapa kalipadaprogram residensial, selebihnyamenggunakan program e-learning. Siahaan (2001) menjelaskan bahwa pembelajaran elektronik (online instruction, e-learning, atau web-based learning), memiliki tiga fungsi utama yaitu fungsi suplemen yang sifatnya pilihan/optional, fungsi pelengkap (complement), dan fungsi pengganti (substitution) pada kegiatan pembelajaran di dalam kelas (classroom instruction). Dilihat dari karakteristik pembelajaran online di atas, pembelajaran dengan menggunakan $e$ learning termasuk kategori pengganti. 
Dalam hal ini, e-learning yang harus dikembangkan bukan hanya sekedar memasukan bahan ajar, namun lebih bersifatkomprehensif,e-learning yang mampu mengakomodasi sistem pembelajaran yang mengatur peran dosen, mahasiswa, pemanfaatan sumber belajar, pengelolaan pembelajaran, sistem evaluasi dan monitoring pembelajaran. Dalam hal ini e-learning yang diperlukan meliputi suatu sistem pengelolaan pembelajaran online terintegrasi yaitu learning management system (LMS).

Pembelajaran online yang menggunakan e-learning sangat ditentukan oleh model LMS yang dikembangkan dan pemanfatannya secara optimal, efektif dan efisien. Elliott Masie, Cisco and Cornellia (2000) menjelaskan, " $E$ learning is delivery of content via all electronic media, including the internet, intranet, extranets, satellite broadcast, audio/ video tape, interactive to, and CD-ROM" Adapun Martin Jenkins and Janet Hanson, Generic Center (2003) mengatakan bahwa e-learning adalah proses belajar yang difasilitasi dan didukung melalui pemanfaatan TIK, Martin tidak secara khusus mengatakan bahwa TIK hanya internet, namun termasuk perangkat yang lainnya. Pendapat lain disampaikan Vaughan Waller (2001) bahwa e-Learning adalah proses belajar secara efektif yang dihasilkan dengan caramenggabungkan penyampaian materi secara digital yang terdiri dari dukungan dan layanan dalam belajar. Konsep digital menurut Waller tersebut mengisyaratkan bukan hanya internet, namun semua perangkat elektronik dewasa ini sudah menggunakan sistem digital.
Hiltz (1994) pernah melakukan studi yang membandingkan efektivitas pembelajaran yang dilakukan secara tatap muka dengan pembelajaran on-line. Hasil dari percobaan ini menunjukkan bahwa pembelajaran online lebih efektif dibanding dengan pembelajaran konvensional. Colorita (2001) menjelaskan bahwa pembelajar yang belajar secara online lebih tinggi tingkat partisipasinya dibanding dengan kelas konvensional. Hasil penelitian Munir (2006) menyatakan bahwa pembelajaran bahasa Melayu dengan menggunakan elektronik (multimedia) lebih signifikan hasilnya dibanding dengan pembelajaran konvensional. Begitu juga hasil penelitian Lengkanawati, NS (2007) mengatakan bahwa pembelajaran bahasa Inggris dengan menggunakan elektronik (multimedia) hasilnya lebih signifikan dibanding dengan menggunakan pembelajaran konvensional.

Ssurvei yang dilakukan oleh Munir (2009) untuk mengetahui literasi komputer mahasiswa di UPI diperoleh data bahwa upaya yang telah dilakukan selama ini oleh UPI dalam membangun sumberdaya manusia dan infrastruktur TIK telah menunjukkan hasil yang baik walaupun masih harus ditingkatkan. Dari data 2,591 orang mahasiswa diperoleh data sebanyak 458 orang (17.7\%) mempunyai literasi komputer sangat tinggi dan tinggi, 1136 orang (43.8\%) mempunyai literasi komputer sedang, dan sejumlah 983 orang (37.9 \%) mempunyai literasi komputer rendah. Adapun bagaimana cara mahasiswa memperoleh literasi komputer didapat angka sebanyak $86.4 \%$ mahasiswa memperoleh literasi komputer karena usaha 
sendiri dan sisanya $13.6 \%$ orang mahasiswa memperoleh literasi komputer yang disediakan oleh universitas. Ini berarti bahwa potensi mahasiswa untuk meningkatkan PBM berbasis TIK sangat tinggi karena literasi komputer yang dimiliki sudah memadai. Potensi mahasiswa ini harus diimbangi oleh universitas dalam menyediakan program-program dalam meningkatkan PBM melalui LMS. Dari kajian inilah penelitian tentang faktor-faktor yang mempengaruhi penggunaan LMS di UPI sangat diperlukan.

LMS dalam PBM berbasis TIK bisa dimaknai dalam tiga paradigma. Pertama, TIK sebagai alat atau LMS sebagai alat berupa produk teknologi yang bisa digunakan sebagai PBM. Kedua, TIK sebagai konten atau LMS sebagai bagian dari materi yang bisa dijadikan isi PBM. Ketiga, TIK sebagai program aplikasi atau LMS sebagai alat bantu untuk PBM secara efektif dan efisien. Penelitian ini memposisikan LMS sebagai alat bantu dalam PBM sehingga rumusan masalah adalah faktor-faktor apakah yang mempengaruhi penggunaan Learning Management System (LMS) di perguruan tinggi (studi kasus di Universitas Pendidikan Indonesia)?

\section{LANDASAN TEORI}

Perkembangan TIK memiliki dampak yang sangat besar dalam berbagai sisi kehidupan. Demikian pula di bidang pendidikan diantaranya untuk menyampaikan materi pembelajaran dengan sistem on-line learning, e-learning ataupun web based learning. Pemanfaatan TIK ini akan membawa perubahan yang sangat berarti baik dalam hal sis- tem pembelajaran yang akan dikembangkan, materi pembelajaran yang akan disampaikan, bagaimana proses pembelajaran akan dilakukan, hambatan-hambatan yang akan dihadapi baik oleh pembelajar, pengajar, penyelenggara pendidikan, masalah jaringan atau media akses yang menjadi jembatan antara sumber belajar dan pihak-pihak yang terlibat dalam proses pembelajaran.

LMS ini berisi materi-materi dalam kompetensi pedagogik dan profesional, yang dibuat dengan kemasan multimedia (teks, animasi, video, sound, FX), diberikan sebagai supplement dan enrichment bagi pengembangan kompetensi pembelajar. LMS menawarkan inovasi pembelajaran yang mencakup inovasi dalam bidang TIK, khususnya yang berbasis virtual melalui web online learning, multimedia dan video conference. LMS pembelajaran berbasis web dikembangkan secara dinamis (dinamic e-learning). LMS adalah pengelolaan interaksi proses pembelajaran berbasis TIK melalui websites. Munir (2008) menyebutkan bahwa unsur yang dimasukkan ke dalam pengembangan LMS harus melibatkan perkembangan psikologi mahasiswa. Di antara unsur-unsur tersebut adalahberhubungan dengan kehidupan yang sebenarnya, 'Hands-on', pendekatan indirect-tematik, menyenangkan, peneguhan positif dan pencarian.

Adapun model pembelajaran yang biasanya dikembangkan di LMS meliputitiga modul materi pembelajaran yaitu: Modul pengukuhan (untuk mengukuhkan pembelajaran pengajar atau mengukuhkan pembelajaran mahasiswa) terdiri dari aktivitas induksi ber- 
tujuan untuk menarik perhatian pelajar kepada topik/pelajaran yang akan dipelajari,penjelasan dan contoh-contoh berkaitan pelajaran yang disampaikan dan latihan sebagai menilai pemahaman pelajar. Modul pengulangan bertujuan untuk mengulang materi pembelajaran bagi mahasiswa yang kurang faham dan perlu mengulangi lagi. Aktivitas ini meliputi penjelasan serta langkah-langkah terperinci untuk menyelesaikan masalah pelajaran, pendekatan pencarian yang mudah yang memerlukan pelajar eksperimen dengan parameter tertentu dan sistem memberi unpan balik dan aplikasi untuk menyelesaikan permasalahan yang memerlukan mahasiswa mengaplikasikankonsep/operasifformula matematika yang mudah yang telah dipelajari. Modulpengayaan adalah modul yang bertujuan untuk memperkaya wawasan mahasiswa terhadap materi pembelajaran yang relevan.

Berdasarkan hasil survei yang dilakukan oleh Chartered Management Institute (CMI) dan Centre for Applied Human Resource Research, Inggris pada hampir 1000 orang manajer dan 12 pemimpin perusahaan besar, ditemukan bahwa prediksi online learning akan menggantikan ruang kelas belum sepenuhnya terbukti. Hal ini didasarkan dari hasil survey bahwa hanya separuh manajer yang telah memanfaatkan sumber-sumber daya online untuk memecahkan permasalahan, dan hanya satu dari 5 yang membuka program elearning yang terstruktur. Kendati demikian, survei melihat, secara umum para manajer memiliki keinginan untuk belajar dan menyadari bahwa internet merupakan sarana untuk itu. Hampir 6 dari 10 melihat online learning sebagai sumber daya yang sangat ampuh untuk pendidikan, yang bisa dimanfaatkan setiap saat. Sepertiga mengaku lebih melihat sumber-sumber daya online sebagai penyedia referensi yang setia, dan satudari4telahmenyadari efektivitasnya dalam segi biaya. Namun, semua itu tidak menjamin bahwa para manajer kemudian mencoba dan memanfaatkannya untuk belajar sesuatu. Kurangnya pemanfaatan fasilitas e-learning ini, diungkapkan oleh setengah responden karena hilangnya sentuhan kemanusiaannya karena hampir tiga perempat dari responden lebih menyukai dialog tatap muka langsung dan lebih dari sepertiga menyatakan, pembelajaran dengan bimbingan tutor lebih efektif. Bagi separuh responden lainnya, rasa bosan merupakan hambatan terbesar, dan seperlima berpendapat bahwa konten yang mereka temukan dalam materi online gagal untuk mengikat dan menarik perhatian mereka. Tiga dari 10 orang mengaku kurang termotivasi untuk menyelesaikan pelajar-pelajaran online tersebut, dengan $17 \%$ beralasan "kurangnya support".

Menyadari hasil survey tersebut di atas maka pengembangan LMS memerlukan perencanaan yang hati-hati dan studi kelayakan yang matang agar pengembangan ini mampu untuk menjawab berbagai permasalahan dalam pembelajaran. Perlu dipastikan bahwa LMS yang dibuat sudah sesuai dengan prinsip-prinsip pedagogi. Untuk pengembangan LMS diperlukan wawasan yang luas tentang program untuk semua level, memfasilitasi pembelajar untuk belajar individual atau kelompok, 
membangun komunikasi yang efektif dan menciptakan masyarakat belajar, dengan demikian dapat ditentukan materi pembelajaran mana yang perlu ditambah, diubah, atau diperbaharui.

Konsep materi pembelajaran berbasis komputer menurut Halimah Badioze Zaman dan Munir (1998) dikembangkan berdasarkan teori kognitif dan teori pembelajaran yang dinyatakan dalam teori-teori, yaitu Adaptive Learning Theory, Preferred Modality Theory, dan Cognitive Flexibility Theory. Teori Adaptive Learning mengandaikan pelajar memasuki pembelajaran pada tahap pencapaian dan pengalaman belajar yang berbeda. Pengajar perlu menggunakan berbagai materi dan strategi pembelajaran untuk memenuhi pencapaian/ pengalaman belajar yang berbeda ini. Ini juga berarti software perlu menggunakan berbagai strategi dan pendekatan untuk memenuhi kehendak yang berlainan ini. Preferred Modality mengandaikan pelajar mempunyai kecenderungan terhadap modalitas yang berbeda. Ini berarti sebagian pelajar lebih suka memahami apabila mendengar, sebagian pelajar lagi lebih suka memahami apabila melihat manakala yang lainnya lebih suka memahami apabila melihat dan mendengar. Software perlu memuatkan kombinasi teks, grafik, suara dan animasi dengan bijak. Cognitive Flexibility mengandaikan apabila suatu materi pembelajaran dipelajari dengan lebih mendalam maka akan lebih pandai dan berkesan apabila pelajar tersebut belajar dengan cara non-linear. Ini karena suatu materi pembelajaran itu merangkum berbagai aspek dan domain. Pengembangan software seharusnya tidak menyerupai metafora buku yang lebih linear atau berurutan dari segi pendekatan penyampaian pengetahuannya.

Sebagai sebuah sistem LMS perlu diketahui tingkat efektivitas dan efisiensinya. Beberapa model telah dibangun untuk menganalisis dan memahami faktor-faktor yang mempengaruhi penggunaan LMS. Salah satu alat ukur yang bisa digunakan adalah Technology Acceptance Model (TAM). TAM pertama kali dikembangkan oleh Davis pada tahun 1989. Menurut Iqbaria (1997), Adam (1992) dan Chin (1995) menyatakan bahwa model TAM paling banyak digunakan untuk penelitian TIK karena model ini sederhana dan mudah untuk diterapkan. TAM diadaptasi dari Theory of Reasoned Action (TRA) yang dikembangkan oleh Ajzen \& Fishbein pada tahun 1975, yaitu teori tindakan yang beralasan dengan satu premis bahwa reaksi dan persepsi seseorang terhadap sesuatu masalah, akan menentukan sikap dan perilaku orang tersebut.

Model TAM menjelaskan perilaku pengguna TIK yang berlandaskan pada kepercayaan (beliefe), sikap (attitude), niat (intention), dan hubungan perilaku pengguna (user behavior relationship). Tujuan model ini untuk menjelaskan faktor-faktor utama dari perilaku penggunaan TIK. Model TAM secara lebih terperinci menjelaskan penerimaan TIK dengan dimensi-dimensi tertentu yang dapat mempengaruhi dengan mudah diterimanya TIK oleh pengguna. Model TAM menempatkan faktor sikap dari tiap-tiap perilaku pengguna dengan dua variabel yaitu kemanfaatan (usefulness) dan kemudahan penggunaan (ease 
of use) yang akan menjelaskan keprilakuan pengguna (Davis, 1989). Model TAM memiliki lima konstruk model TAM yaitu Perceived Ease of User, Perceived Usefulness, Attitude Toward Using, Behavioral Intention to Use, dan Actual Sistem Usage (Davis, 1989).

Perceived Ease of User, yaitu persepsi pengguna tentang kemudahan penggunaan sebuah teknologi sebagai ukuran kepercayaan bahwa LMS dapat dipahami dan digunakan dengan mudah. Indikator kemudahan penggunaan LMS, antara lain: (i) LMS sangat mudah dipelajari, (ii) LMS sangat mudah mengerjakan aktivitas yang diinginkan dan dibutuhkan oleh pengguna, (iii) LMS sangat mudah meningkatkan keterampilan pengguna, dan (iv) LMS sangat mudah dioperasikan.

Perceived Usefulness, yaitu persepsi pengguna terhadap kemanfaatan sebagai ukuran penggunaan suatu LMS yang dapat dipercaya dan akan bermanfaat bagi orang yang menggunakannya. Kemanfaatan LMS meliputi: (i) kegunaan yang mencakup dimensi: menjadikan pembelajaran lebih mudah, bermanfaat, menambah produktivitas, dan (ii) efektivitas yang mencakup dimensi: mempertinggi efektfivitas, mengembangkan kinerja pembelajaran.

Attitude Toward Using, yaitu sikap pengguna terhadap penggunaan LMS yang berbentuk penerimaan atau penolakannya sebagai dampak bila seseorang menggunakan suatu LMS dalam pembelajarannya. Salah satu aspek yang mempengaruhi perilaku individu itu adalah sikap (attitude). Sikap seseorang terdiri atas unsur kognitif ( $\operatorname{cog}$ nitive), afektif (affective), dan komponen- komponen yang berkaitan dengan perilaku behavioral component.

Behavioral Intention to Use, yaitu perilaku penggunaLMS untuktetap menggunakanLMS. Tingkat penggunaan mahasiswa terhadap LMS dapat diprediksi dari sikap perhatiannya terhadap LMS tersebut. Misalnya keinginan pengguna dalam menambah peripheral pendukung LMS, motivasi untuk tetap menggunakan LMS, dan keinginan untuk memotivasi mahasiswa lain. Dan Actual Sistem Usage, yaitu keadaan yang nyata dalam penggunaan LMS yang bentuk pengukurannya dapat dilihat dari frekuensi dan durasi waktu penggunaan LMS.

\section{METODE}

Metode penelitian yang digunakan dalam penelitian ini adalah metode eksplanatori mengenai hubungan kausal (sebab akibat) dari variabel-varibel yang diamati dan diteliti. Pengambilan sampel diacak dari mahasiswa di UPI dan data dikumpulkan dengan menggunakan metode survei melalui instrumen kuesioner berbasis web selama empat bulan antara bulan september sampai dengan bulan desember 2009 bertempat di Direktorat Teknologi Informasi dan Komunikasi, UPI. Analisis statistikdeskriptifdilakukan untuk menelaah distribusi frekuensi ukuran pemusatan dan penyebaran data tentang karateristik sampel (responden) dan indikator-indikator variabel Perceived Usefulness (PU) meliputi: lebih cepat (Y1), meningkatkan kinerja (Y2), lebih berdaya guna (Y3), lebih mudah (Y4), meningkatkan produktivitas (Y5) dan lebih efektif (Y6), Perceived Ease of Use 
(PEOU) meliputi: mudah dipahami (X1), mudah dioperasikan (X2) dan mudah digunakan (X3). Intention to Use (ITU) meliputi: keinginan untuk menggunakan (Y7) dan keinginan untuk sharing (Y8). Actual Usage Behavior (AUB) meliputi: frekuensi penggunaan (Y9) dan lama menggunakan (Y10).

Dalam menguji hipotesis peneliti menggunakan metode statistik multivariat dengan menggunakan software SPSS. Adapun model analisis data dalam penelitian ini sebagai berikut.

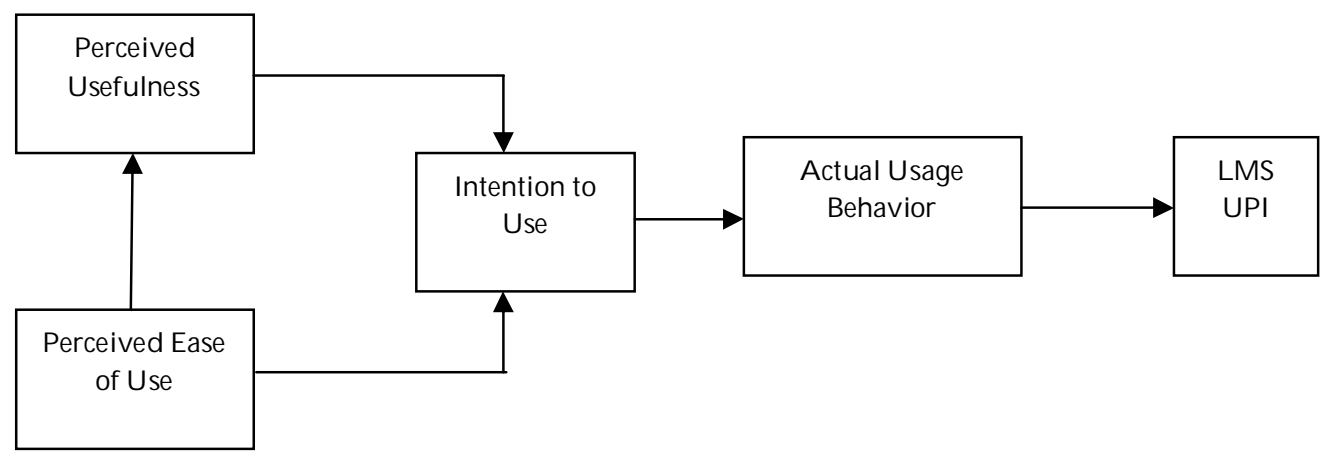

Gambar 1. Model Analisis Data

Dengan menggunakan model analisis data di atas, maka disusun hipotesis deskriptif dan hipotesis statistik sebagai berikut.

Hipotesis deskriptif :

$\mathrm{H}_{1}$ : Diduga PEOU berpengaruh terhadap PU.

$\mathrm{H}_{2}$ : Diduga PEOU berpengaruh terhadap ITU.

$\mathrm{H}_{3}$ : Diduga PU berpengaruh terhadap ITU.

$\mathrm{H}_{4}$ : Diduga ITU berpengaruh terhadap AUB

Hipotesis statistik :

Variabel laten eksogen :

$\mathrm{H}_{0}: \gamma_{\mathrm{n}}=0$; Tidak berpengaruh (Terima $\mathrm{H}_{0}$ )

$\mathrm{H}_{1}: \gamma_{\mathrm{n}} \neq 0$; Berpengaruh (Tolak $\left.\mathrm{H}_{0}\right)$

Variabel laten endogen:

$\mathrm{H}_{0}: \beta_{\mathrm{n}}=0$; Tidak berpengaruh (Terima $\left.\mathrm{H}_{0}\right)$
$\mathrm{H}_{1}: \beta_{\mathrm{n}} \neq 0 ;$ Berpengaruh $\left(\operatorname{Tolak} \mathrm{H}_{0}\right)$

Pengujian dilakukan dengan melihat nilai Signifikansi (Sig) yang diperoleh tiap variabel kemudian dibandingkan dengan nilai $\alpha ́ \alpha$ (0.05). Jika Sig $\leq 0.05$ maka Tolak $\mathrm{H}_{0}$.

\section{HASIL DAN PEMBAHASAN}

Bagian ini akan mengemukakan hasil penelitian yang telah diperoleh melalui beberapa pendekatan penilaian untuk mengetahui faktor-faktor apakah yang mempengaruhi penggunaan LMS diUniversitasPendidikanIndonesia. Untuk menjawab semua persoalan yang berkaitan dengan ini, data kuantitatif dianalisis seperti dijelaskan di bawah ini dan data kualitatif dikemukakan bersamaan dengan pembahasan hasil penelitian. Jumlah responden sebanyak 1109 mahasiswa dengan profil terbesar 
mahasiswa yang berada di tingkat IV $(37,32 \%)$, berusia antara $20-21$ tahun $(42,24 \%)$, sebagian besar berasal dari FPMIPA (22,50\%). Laki-laki $(37,24 \%)$ dan perempuan $(62.76 \%)$.

Hasil pengujian validitas terhadap variabel laten eksogen PEOU (Perceived Ease of Use) adalah masing-masing variabel indikator X1 (mudah dipahami), X2 (mudah dioperasikan), dan X3 (mudah digunakan) secara signifikan merupakan konstruktur yang valid (Tolak $\mathrm{H}_{0}$ ) bagi variabel laten PEOU. Terbukti dari nilai yang diperoleh $\mathrm{X} 1$ dan $\mathrm{X} 2$ pada uji parameter model pengukuran variabel PEOU dengan signifikansi (sig)/ taraf nyata ( $\alpha$ ) 0.05 di atas nilai kritis $(\operatorname{sig} \leq \alpha)$. Sedangkan parameter pengukuran X3 ditetapkan bernilai 1. Karena ditetapkan secara apriori, maka parameter X3 tidak di uji. Akibatnya, variabel pengukuran $\mathrm{X} 3$ merupakan konstruktor yang valid bagi variabel laten PEOU. Maka dapat dikatakan bahwa LMS mudah dipahami, mudah digunakan dan mudah dioperasikan.

Adapun hasil pengujian validitas terhadap variabel endogen PU (Perceived Usefulness) diperoleh hasil bahwa variabel indikator Y2 (meningkatkan kinerja), Y4 (lebih mudah), Y5 (meningkatkan produktifitas) dan Y6 (lebih efektif) secara signifikan merupakan konstruktor yang valid (Tolak $\mathrm{H}_{0}$ ) bagi variabel laten PU. Terbukti dari nilai yang diperoleh $Y 4, Y 5$ dan $Y 6$ pada uji parameter model pengukuran variabel PU dengan signifikansi (sig) taraf nyata

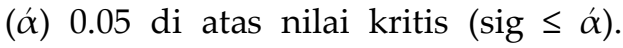
Parameter pengukuran Y2 ditetapkan bernilai 1. Karena ditetapkan secara apriori, maka parameter Y2 tidak di uji.
Akibatnya, variabel pengukuran Y2 merupakan konstruktor yang valid bagi variabel laten PU. Maka dapat dikatakan bahwa dengan menggunakan LMS maka dapat meningkatkan kinerja, berbagi pengetahuan lebih mudah, dapat meningkatkan produktivitas dan lebih efektif dalam berbagi pengetahuan. ITU (Intention to Use) menghasilkan nilai variabel indikator Y7 (keinginan untuk menggunakan), dan Y8 (keinginan untuk sharing) secara signifikan merupakan konstruktor yang valid (Tolak $\mathrm{H}_{0}$ ) bagi variabel laten ITU. Terbukti dari nilai yang diperoleh $Y 8$ pada uji parameter model pengukuran variabel PRP dengan signifikansi (sig)/taraf nyata ( $\alpha$ ) $0.05 \mathrm{di}$ atas nilai kritis $(\operatorname{sig} \leq \alpha)$. Parameter pengukuran Y7 ditetapkan bernilai 1 . Karena ditetapkan secara apriori,maka parameter $Y 7$ tidak di uji. Akibatnya, variabel pengukuran Y7 merupakan konstruktor yang valid bagi variabel laten ITU. AUB (Actual Usage Behavior) diketahui bahwa masing-masing variabel indikator Y9 (Frekuensi penggunaan), dan Y10 (Lama menggunakan) secara signifikan merupakan konstruktur yang valid (Tolak $\mathrm{H}_{0}$ ) bagi variabel laten AUB. Nilai yang diperoleh Y10 pada uji parameter model pengukuran variabel AUB dengan signifikansi (sig)/taraf nyata (ó) 0.05 di atas nilai kritis $(\operatorname{sig} \leq \alpha)$. Parameter pengukuran Y9 ditetapkan bernilai 1. Karena ditetapkan secara apriori, parameter Y9 tidak di uji. Akibatnya, variabel pengukuran Y9 merupakan konstruktur yang valid bagi variabel laten AUB.

Hasil pengujian reliabilitas $R^{2}$ menunjukkan hasil sebagai berikut $\mathrm{X} 1$ (0.897), X2 (0.960) dan X3 (0.920) se- 
dangkan variabel laten AUB berkontribusiterhadapvarians $Y 9$ sebesar $97,4 \%$, variabel indikator Y10 merupakan indikator yang paling kurang realibel dari variabel laten $A U B$, karena nilai $R^{2}$ yang dimilikinya adalah paling kecil dibandingkan dengan variabel indikator lainnya. Dari hasil reliabilitas gabungan dapat dinyatakan bahwa PEOU, PU, ITU dan AUB memiliki nilai Composite Reliability di atas 0.70. Batas nilai kritis yang direkomendasikan untuk Composite Reliability adalah 0.70. Variabel laten PEOU, PU, ITU dan AUB mememuhi batas nilai Variance Extracted yaitu $\geq$ 0.50 . Dengan demikian, dapat dikataan bahwa masing-masing variabel memiliki realibilitas yang baik.

Pengujian atau analisa terhadap statistik deskriptif diperoleh angka berupa nilai mean (rata-rata): Y1 (10,3280), Y2 $(9,86023), Y 3(10,9182), Y 4(9,9652), Y 5$ $(10,6591), \quad Y 6(8,7568), Y 7(9,5591), \quad Y 8$ $(11,8710), \quad Y 9(4,5712), Y 10(3,2856), X 1$ $(8,9924), \quad X 2(9,9394), X 3(9,9424)$. dan Standar Deviasi Y1 $(2,67821), \quad Y 2$ $(3,59174), Y 3(2,71334), \quad Y 4(3,64478)$, Y5 (1,93323), Y6 (3,59198), Y7 (2,98510), Y8 (1,97809), Y9 (1,72135), Y10 (0.98454), X1 (1,99789), X2 (1,95009), X3 (1,68673). Adapun hasil uji normalitas berada pada kisaran antara -2.47 sampai 2.47. Distribusi normal secara multivariate nilainya mendekati di kisaran 2,66. Ini berarti data memenuhi syarat untuk dilakukan analisis selanjutnya dengan nilai nilai Z Score dari setiap variabel berada pada kisaran \pm 3.0 .

Hasil pengujian hipotesis yang dilakukan diperoleh hasil sebagai berikut: $\mathrm{H}_{1}$ (PEOU - PU) nilai signifikansi (0.000), $\mathrm{H}_{2}$ (PEOU - ITU) nilai signifi- kansi (0.000), $\mathrm{H}_{3}$ (PU - ITU) nilai signifikansi (0.000), dan $\mathrm{H}_{4}$ (ITU - AUB) nilai signifikansi (0.000). Disebabkan semua hasil uji hipotesis menghasilkan nilai signifikansi (.000) lebih kecil daripada signifikansi 0.05 , maka semua hipotesis nol ditolak. Ini berarti bahwa secara statistik terdapat pengaruh yang signifikan dari variabel PU, PEOU, ITU, dan AUB terhadap penggunaan $\mathrm{LMS}\left(\mathrm{H}_{0}\right.$ di tolak).

Berdasarkan hasil statistik tersebut diatas berarti bahwa PUdan PEOU berdampak positif terhadap ITU. Setelah mahasiswa ITU terhadap LMS, maka akhirnya berpengaruh pada AUB dalam menggunakan LMS. Artinya, semakin mudah LMS digunakan maka semakin meningkat kemanfaatan LMS tersebut dan juga berdampak terhadap keinginan untuk menggunakan LMS. Karena LMS menggunakan aplikasi web yang semua mahasiswa sudah mengetahui, dan sering menggunakannya melalui browser seperti Internet Explorer di website: Ims.upi.edu. LMS yang diteliti menurut persepsi mahasiswa dapat dengan mudah dipahami, dioperasikan dan mudah digunakan untuk berbagi pengetahuan yang dimiliki mahasiswa dan juga untuk mencari pengetahuan yang diperlukan mahasiswa, tanpa harus menginstal aplikasi khusus pada terminal komputernya dalam menggunakan.

Dilihat dari kemanfaatannya PU dengan menggunakan LMS berpengaruh terhadap ITU LMS. Ini berarti bahwa LMS memiliki kemanfaatan lebih cepat, dapat meningkatkan produktivitas, lebih efektif, lebih mudah, meningkatkan kinerja, dan berdaya guna. Unsur atau 
fasilitas yang ada di dalam LMS seperti berhubungan dengan kehidupan yang sebenarnya, 'Hands-on' pendekatan indirect-tematik, menyenangkan, peneguhan positif dan pencarian memudahkan mahasiswa untuk melaksanakan proses pembelajaran. Ditambah lagi dengan pembagian materi pembelajaran ke dalam beberapa modul materi pembelajaran yaitu: modul pengukuhan, modul pengulangan, dan modul pengayaan. Dengan modul pengukuhan mahasiswa merasakan tertarik terhadap materi pembelajaran sehingga ingin memiliki keinginan untuk belajar dan berlatih. Apabila belum terkuasai juga materi pembelajaran tersebut maka terdapat modul pengulangan dan disediakan juga materi-materi pembelajaran yang lain untuk pengayaan atau perluasan wawasan.

Dengan adanya kemudahan dan manfaat yang dirasakan oleh mahasiswa terhadap LMS maka menimbulkan persepsi keinginan untuk menggunakan LSM. Sikap penerimaan mahasiswa terhadap penggunaan LMS yang mencerminkan bahwa LMS diterima dengan baik oleh mahasiswa. Mahasiswa dapat merasakan adanya peningkatan terhadap kognitif (cognitive), afektif (affective), dan psikomotornya.

Perilaku mahasiswa AUB terhadap penggunaan LMS sudah menunjukkan arah yang positif sehingga perhatian dan keinginan pengguna terhadap LMS semakin banyak dan komplek. Indikator ini akan mempengaruhi terhadap aktualisasi mahasiswa terhadap pembelajaran dengan menggunakan LMS. Kenyataannya frekuasi penggunaan LMS semakin meningkat dan durasi waktu penggunaannya semakin lama. Jadi AUB LMS dipengaruhi oleh ITU, perilaku pengguna dalam menggunakan LMS muncul karena adanya keinginan untuk menggunakan. Pada penelitian ini, perilaku yang positif dalam menggunakan LMS antara lain frekuensi dalam menggunakan LMS dan lamanya waktu yang dipakai dalam menggunakan LMS.

\section{KESIMPULAN}

Berdasarkan hasil penelitian disimpulkan bahwa faktor kemudahan penggunaan LMS (PU) dan faktor kemanfaatan LMS (PEOU) berdampak positif terhadap faktor sikap mahasiswa terhadap penggunaan LMS (ITU). Setelah mahasiswa memiliki sikap positif terhadap pembelajaran dengan menggunakan LMS maka akhirnya berpengaruh terhadap prilaku mahasiswa dalam menggunakan LMS yang pada akhirnya mahasiswa dapat mengaktualisasikan pembelajaran berbasis LMS (AUB). Artinya, semakin mudah LMS digunakan maka semakin meningkat kemanfaatan LMS tersebut dan juga berdampak terhadap keinginan untuk menggunakan LMS. Karena LMS menggunakan aplikasi web yang semua mahasiswasudahmengetahui, dan sering menggunakannya melalui browser seperti Internet Explorer atau yang sejenisnya melalui Ims.upi.edu, sehingga LMS dapat dengan mudah dipahami, dioperasikan dan mudah digunakan untuk berbagi pengetahuan yang dimiliki mahasiswa dan juga untuk mencari pengetahuan yang diperlukan mahasiswa. Jadi hasil penelitian menyimpulkan bahwa faktor Perceived Usefulness (PU), Perceived Ease 
of Use (PEOU), Intention to Use (ITU), Actual Usage Behavior (AUB) secara signifikanmempengaruhipenggunaan LMS secara efektif dan efisien dalam menunjang PBM.

\section{UCAPAN TERIMA KASIH}

Terima kasih diucapakan kepada DP2M Ditjen-Dikti yang telah membiayai penelitian ini. Terima kasih juga diucapkan kepada semua pihak yang telah membantu terbitnya artikel ini.

\section{DAFTAR PUSTAKA}

Adams, D. A., Nelson, R. R., \& Todd, P. A. 1992. "Perceived usefulness, Ease of Use, and Usage of Information Technology: A Replication". MIS Quarterly, 16, 227-247.

Ajzen, I., \& Fishbein, M. 1980. Understanding Attitudes and Predicting Social Behavior. Englewood Cliffs, NJ: Prentice-Hall.

Bagozzi, R. P. 2007. “The Legacy of the Technology Acceptance Model and a Proposal for a Paradigm Shift". Journal of the Association for Information Systems, 8(4), 244-254.

Davis, F. D. 1989. "Perceived Usefulness, Perceived Ease of Use, and User Acceptance of Information Technology".MIS Quarterly, 13(3), 319-340.

Davis, F. D., Bagozzi, R. P., \& Warshaw, P. R. 1989. “User Acceptance of ComputerTechnology: A Compa- rison of Two Theoretical Models". Management Science, 35, 982-1003.

Hiltz, S.R. 1994. The Virtual Classroom: Learning without Limits via Computer Networks. New Jersey: Ablex Publishing Corporation.

Munir. 2006. “The Effectiveness of Multimedia in Education Package to Motivate Literacy (MEL) amongst Preschool Children". COMPARE $\mathrm{I}(2)$. Journal of the Comparative Educational Society of Asia.

Munir. 2008. Kurikulum Berbasis Teknologi Informasi dan Komunikasi. Bandung: Alfabeta.

Munir. 2009. “Peta Literasi Komputer Mahasiswa di Universitas Pendidikan Indonesia". Mimbar Pendidikan, XXVIII(1). Universitas Pendidikan Indonesia.

Munir. 2009. Pembelajaran Jarak Jauh Berbasis Teknologi Informasi dan Komunikasi. Bandung, Penerbit: Alfabeta.

Siahaan, Sudirman. "E-learning (Pembelajaran Elektronik) sebagai Salah Satu Alternatif Kegiatan Pembelajaran. http:/wwww.depdiknas.go.id.diakses tanggal $27 \mathrm{Agu-}$ stus 2009.

Waller, Vaughan and Wilson, Jim. 2001. A Definition for E-Learning" in Newsletter of Open and Distance Learning Quality Control. October 2001. (sumber dari internet: 16 September 2002 http://www.odlqc.org.uk/odlqc /n19-e.html). 